\title{
Elvyda Martišauskienè
}

\section{DVASINIO UGDYMO SVARBA DABARTIES IR ATEITIES MOKYKLAI: M. LUKŠIENĖS İŽVALGOS}

\begin{abstract}
Anotacija. Straipsnyje pristatoma dvasinio ugdymo samprata ir ryškinama jo svarba, keičiantis ugdymo paradigmai, kurios ịkvèpëja ir koordinatoré - M. Lukšienè. Ji pamatiniais Lietuvos švietimo koncepcijos postulatais laiko kultūros ir asmens abipusę sąveiką, turinčią persmelkti visą mokyklos gyvenimą. Tuomet vertybès tampa kaitos ir tęstinumo garantu, bendruoju vardikliu pertvarkant ugdymo procesą. Straipsnyje pateikiama konceptualiu M. Lukšienès įžvalgų analizė, aptariami šiuolaikinès mokyklos ugdymo problemų židiniai, svarbūs tiesiant kelius ị ateities mokyklą.
\end{abstract}

Esminiai žodžiai: dvasinis ugdymas, asmens ir kultūros sąveika, dvasinès vertybès, ugdymo problemų židiniai.

\section{Ivadas}

\section{Dvasinio ugdymo(si) kontūrai}

Ugdymas yra svarbiausia, bet kartu ir sudettingiausia žmogaus veiklos dalis, nukreipta i̇ žmogaus kaip asmens sklaidos tobulinimą(si). Ir nors ugdymas(is) siekia giliausius žmonijos istorijos klodus, nors galima remtis autentiškomis patirtimis, XXI a. ugdytojams kyla daug problemu, kurių ištakos didele dalimi yra žiniu apie žmogaus egzistenciją lygis. Jị lemia daug veiksnių ir pirmiausia žinių ịvairové. Problema ta, kad stambiausiu planu žinios skiriamos ị dvi grupes: mokslo ir tikejjimo. Pirmosios sistemina ir apibendrina psichofizinę žmogaus būties dalị, daugiau ar mažiau prieinamą pozityvistiniams tyrimams, todèl tiek materialistinei, tiek pragmatinei metodologijai priimtinos. Tikejjimas saistomas su fenomenologinemis į̌̌valgomis, palieka daug vietos intuityvumui, intencionalumui ir kt., kas netenkina mokslo validumo, pakartojamumo kriterijų. Be to, tikèjimas taip pat nevienalytė sąvoka, apimanti religijos išpažinimą ir tikèjimą dalykų tikrumu, pozityviu žvilgsniu į ateitį, dvasinès būties pajauta. Ir nors mokslo ir tikèjimo žinių apie žmogų skirtingos prieigos, tačiau akivaizdu, kad jos abi svarbios žmogaus, kartu ir jo ugdymo, supratimui, nes išmintis, mokslininkų nuomone, pasiekiama tik jų susiliejimu [3].

Ivairiu sričių šiuolaikiniai antropologiniai tyrimai leidžia žmogų laikyti „trijų būties sluoksnių fizinio, psichinio ir dvasinio - sankirta" [1, p. 342].
Jei pirmieji du sluoksniai daugiau vienareikšmiškai apibrèžti, tai dvasinis sulaukia skirtingu požiūriu nuo neapčiuopiamos metaforos iki aiškiai apibrèžto dèmens, suponuojančio žmogaus asmenybiškumą, $A \check{s}$, steigiančio žmogaus kaip asmens vienumą, t. y. subordinuojančio žmogaus egzistenciją, išryškinant svarbiausią matmenị - galią transcenduoti tikrovę (V. Franklis, K. Wojtyła, G. W. Allportas, J. Ravenas, A. Lobato), nes „žmogus yra žmogus tik tiek, kiek suvokia save transcendencijos akivaizdoje, negana to, - jis yra asmenybe tik tiek, kiek yra suasmeninamas jos akivaizdoje, kiek persmelkiamas transcendencijos šauksmo" [1, p. 344]. Tai leidžia asmeniui, tariant K. Wojtyłos (2007) žodžiais, save turèti ir save valdyti, nes „kūnas yra galimybè realizuoti dvasią“ " 6, p. 63], apsispręsti ir būti atsakingam, nes ,iš dvasinès būties atsiranda racionali ir laisva valia“" [ten pat, p. 67], ar jausti poreikius, kurių negali tenkinti žemiški dalykai, ir taip kreipti mintị ị antgamtinio pasaulio realumą, amžinujjų vertybių buvimą ir kt.

İvairiarialypès (filosofinès, psichologinès, pedagoginès) žmogaus dvasinės būties aptartys (minètų ar kitų autorių: M. S. Kagano, B. Kuzmicko, A. Maslow, A. Maceinos, L. Jovaišos, B. Bitino, V. Aramavičiūtès, D. Verbylaites ir kt.) sudaro prielaidas išskirti pedagoginiu požiūriu svarbiausius dvasinès dimensijos požymius. Kaip minèta, dèl jos žmogus yra laisvas, galintis transcenduoti laiką ir erdvę, pats kurti save ir transformuoti tikrovę. Tèvai dvasinès dimensijos neperduoda, bet ir negali jos atimti, net susargdinti, nes dvasios ištakos antgamtinès, tačiau ju sklaida akivaizdi žmogaus ir pasaulio realybèje. Pedagoginiu aspektu tai reiškia, kad visi žmonès šią galią turi, kad būtent ji suponuoja asmens autentiškumą, kuris nuo kūdikystès „Aš pats“ lydi žmogų visą gyvenimą, bet dažnai tampa ugdymo problema, kai norima ją eliminuoti, ar dèl nesupratimo, kad save valdyti yra prigimtinè žmogaus teisè, ar dèl to, kad šia teise netinkamai naudojamasi, apribojant ar visiškai paneigiant kitų asmenų tokią pat teisę. Tai atsitinka tada, kai galia laisvai pasirinkti taip pat laisvai nesusiejama su kita dvasinès būties galia, sąžine, dar tiksliau, galia pažinti tiesą. Tik jų sąlytis laiduoja žmogaus, kaip asmens, laisvę. Ugdymo paskirtis yra šią sąsają gilinti, plèsti tiek visos tikrovès pažinimo (mokslo, tikèjimo aspektais), tiek santykių darnos 
(dorovès), tiek tobulumo siekimo (grožio) linkmèmis, taip pažistamomis nuo Platono triados - tiesos, gèrio ir grožio lydinio, kurio visi matmenys iš vienos būties tiesos kilę, bet būties tiesą skirtingais aspektais skleidžia. Kad įvairiaspalvès tiesos gijos persmelktu žmogaus ir žmonijos būtị, taptų jų fundamentine jungtimi, svarbi meilè, empirinè dvasios raiška, igalinanti asmenị koncentruotis ị kitą asmenị (asmenis), suprasti, pajausti jo (jų) problemas, rūpintis, išgyventi dèl jų, padèti spręsti. Todèl pedagogikos giliausia esme paremta meile, ugdymo procese daugiausia įsikūnijančia humaniškumo, nacionalumo, demokratiškumo principais.

Paviršutiniškai žvelgiant, dvasinį ugdymą, suprantant jo transcendentines ištakas, linkstama sieti tik su religiniu ugdymu, todèl daugelyje šalių sukelia kitaip manančiujų pasipriešinimą. Tačiau galvojant, kad dvasinio ugdymo ištakos - laisvès, tiesos, meilès simbiozé, apimanti visas būties sritis, - susidaro prielaidos dvasinį ugdymą laikyti viso ugdymo pagrindu. Todèl keliama problema, ar / kaip švietimo reforma siejama su dvasiniu ugdymu, kiek ji atliepia reformos ịkvèpëjos daktarès M. Lukšienès pedagoginę mintį.

Tyrimo objektas - M. Lukšienès pedagoginis palikimas.

Straipsnio tikslas - atskleisti M. Lukšienès požiūrị ị dvasinio ugdymo svarbą dabarties ir ateities mokyklai.

\section{Keliami uždaviniai:}

1. Išryškinti požiūrị ị dvasinio ugdymo pamatą asmens ir kultūros saitus.

2. Parodyti dvasinių vertybiu kaip ugdymo kaitos ir tęstinumo garanto vietą ugdymo procese.

3. Aptarti šiuolaikinius ugdymo problemų židinius.

Straipsnis grindžiamas sistemine analitine M. Lukšienès pedagoginio palikimo, taip pat filosofinès, psichologinès, pedagoginès literatūros, švietimo dokumentų analize.

\section{Asmens ir kultūros saitai - dvasinio ugdymo pamatas}

Švietimo reformos idèjos brandino Lietuvos nepriklausomybès atkūrimą ir tiesẻ kelius jai įtvirtinti. Tam reikèjo rasti gelminius šaltinius, kurie maitintų nepriklausomybès siekius, dètu pamatus valstybingumo sklaidai visose srityse, o švietimas atliktų savo svarbiausią funkciją. Jais išmintingai pasirinkta asmuo ir kultūra, aiškiai suvokiant jų saitus ir ypatingą svarbą atkuriant nepriklausomybę: asmuo suprantamas „kaip pagrindinis visuomenés procesų matas bei kriterijus, turint [omeny] visu pirma jo esminę žmoniškumo žymę - dvasingumą“ [7, p. 159], o kul- tūra - kartu su V. Kavoliu, kaip tai, „kas žmonių pagaminta, ir tai, kas jiems ką nors reiškia", ar su A. L. Kroeberiu, kaip ,žmogaus veiklos b ù d a s i r vertybè s " [ten pat, p. 352], suponuojančiais visuminị kultūros vaizdą, jauseną, mąstyseną. Todèl ìvairiais atžvilgiais šie fenomenai iš esmės yra susiję ir siekia giliausius ugdymo tikrovès ryšius, suponuojančius bendrybes. Tačiau ugdymo ir kultūros bendrybès, $M$. Lukšienès nuomone, prasideda nuo to, kaip naujovès igyvendinamos, atmetant ar ieškant sąsajų su ankstesnèmis idèjomis, dariniais, elgesiu.

Žmogus, kaip asmuo, visada remiasi i dvasinę dimensiją, leidžiančią būti laisvam, kurti save, vadovaujantis aukščiausiais, tiesos, matais, kurie, kaip žinia, šaknijasi dvasinëje dimensijoje, o žmogaus sąmonę pasiekia kaip sąžinès balsas. Nereikia stebètis, kodèl mūsų protèviai, kurių daugelis buvo beraščiai, galëjo bręsti kaip taurios asmenybès, skaidriai ịprasminę žmogaus egzistencinius pamatus kultūroje, iš kurios patys sėmėsi išminties ir kurią pildè naujomis patirtimis, sudarančiomis sąlygas išlikti skaudžiausiais istorijos lūžiais. Pasak M. Lukšienès, „kultūra tai dvasinè tautos raiška" [ten pat, p. 166], ịkūnijusi iškiliausius ankstesnių kartų ir dabarties žmonių dvasios judesius. Ispanų filosofo A. Lobato nuomone, „žmogaus sielos dvasiškumui būdinga kultūrinè dimensija, kuri yra jai prigimta“ [6, p. 70]. Todèl asmens ir kultūros sanglauda visada yra gyva versmè, ištekanti iš dvasinès žmogaus būties gelmių, ir maitina naujas kartas, teikia joms savęs ir kultūros kūrimui statybines medžiagas, bet neslopina jų kūrybingo naudojimo, nes kūryba yra aukščiausia dvasingumo išraiška, nukreipta tiek ị autokreaciją (savęs kūrimą), tiek ị aplinkos keitimą.

Asmens ir kultūros saitai būna įvairių lygių: atkuriant Lietuvos valstybę, pasak Daktarés, lygiuotis ị dorovinị iškilumą „buvo inteligento garbès reikalas“ [7, p. 167]. Tuo tarpu atkuriant nepriklausomybę, pastebima, kad „esame išaugę intelektualiniu atžvilgiu, bet labai sumenkę etiniu“, be to, „mes jau nebeturime visuminio kultūros jutimo (retos išimtys)“ [ten pat], o „nepriklausomybe - tai ir dvasinis aktas, tai ir kultūros puoselèjimo aktas, tai naujos švietimo sistemos kūrimas" [ten pat, p. 168]. Taikliai pasakyta. Kartu akivaizdu, kur link reikia sukti mokyklos vairą. Tad ne be M. Lukšienès ịtakos Lietuvos bendrojo lavinimo mokyklos bendrosiose programose konstatuojama, kad „Lietuvos mokykla yra įsipareigojusi tautos kultūrai. Ji rūpinasi tautinès tapatybès išsaugojimu, tautos kultūros kūrybiniu pajègumu ir jos istoriniu tęstinumu. Mokykla skatina <...> nuolat atsižvelgti i šiandienès civilizacijos raidos tautinei kultūrai keliamus uždavinius ir kūrybingai tradicines vertybes plè- 
toti“ [ten pat, p. 313]. Tai dideli, šiuolaikiškai sakant, ambicingi uždaviniai, iškelti remiantis egzistenciniu, humanistiniu, konstruktyvistiniu požiūriu į žmogu ir kultūrą, siekiant dvasiniais ryšiais susieti visumiškumą, tęstinumą ir kaitą. Jie turèjo persmelkti ugdymo turini, jungiant konceptualias idèjas, kuriant universalias ir integruotas programas, visais parametrais keisti ugdymo procesą, atveriant duris laisvojo ugdymo paradigmai, skatinti dorovinius poslinkius.

Pastebètina, kad „visa švietimo sistema <...> žmonijos kultūros veiksnys, kultūros perdavimo labai veiksminga grandis. Todèl ne tas pat, kaip ji plètojama. Kartu švietimo sistema - tai ir parengimas, ir pasirengimas kultūrą toliau tęsti, plètoti, kurti“ [ten pat, p. 306]. Tačiau „<...> kaitoje turi išlikti du pastovūs dalykai: žmoniškumo ir tautos idejos, nes tai yra mūsų dvasinès gyvybès laidas" [ten pat, p. 125], kuris atskiro asmens dorovinį horizontą glaudžiai susieja su tautos interesais, likimu. Šis mastelis neparankus tiems, kurie žmoniškumą saisto vien su artimos aplinkos ar su globalios erdvès mastais, lengvai nuslystančiais $\mathfrak{i}$ abstrakčius, neịpareigojančius santykius. Kultūra, kaip ir apskritai bet kuris reiškinys, turi remtis ị vienumos pojūtị, kurị asmens atveju steigia dvasinè galia transcenduoti psichofizinę tikrovę [1], kultūros atžvilgiu - asmenų, susietų dvasinès raiškos saitais, bendrystés pajauta, nes, kaip pastebi A. Jokubaitis, teiginys „moralinė atsakomybè neturi tautybès, visada skamba daug įtikinamiau, negu teiginys apie kosmopolitini politinès atsakomybès pobūdị“ [2, p. 11]. Taip yra todèl, kad doroviniai dalykai siekia žmoniškumo ištakas, implikuojančias tautinę, o kartu ir kultūrinę raišką. Švietimo sistema grindžiama nuostata, kad visas „ugdymas laikomas kultūros proceso dalimi, jo sandu“ " 7, p. 48], kylančiu iš tų pačių dvasinių šaknų, todèl asmens ir kultūros jungtys, jų stiprëjimas ir dinamika yra viso ugdymo proceso arena, o dvasinis ugdymas - centriné, visa fokusuojanti, vienijanti grandis.

\section{Dvasinès vertybès kaip ugdymo kaitos ir tęs- tinumo garantas}

Atsigręžus i dvasinius ugdymo pamatus, darosi akivaizdu, kad dvasinių vertybių ugdymas gali būti tas atžvilgis, kuris laiduoja švietimo sistemos kaitos ir tęstinumo vienovę. Dvasingumą M. Lukšienė apibūdina penkiais aspektais kaip: orientaciją ,ị vertybes, sudarančias žmogaus esmę, vadinasi, dvasines" [7, p. 131]; gilų jų ne tik supratimą, bet ir išgyvenimą; poreiki jas patirti; skleidimą kitiems, „nepasiekusiems to išsivystymo laipsnio" [7, p. 131]; vertybiu kūrimą. Tai išplètota vertybių internalizacijos schema, atskleidžianti vertybių ugdymo, o kartu ir dva- singumo raidą kūrybos, aukščiausio dvasinės raiškos lygmens, link, nes tokiu būdu asmuo gali daugiausia išplètoti savo potencialą, įsilieti, drauge su kitais dalyvauti ịvairialypiame kultūriniame gyvenime, plètoti ji, sykiu gaivinant, eskaluojant praeities, dabarties ir ateities kartų dvasinę jungtí, nes „tauta, kaip ir žmogus, neturinti savo dvasinio pasaulio, žūsta" [ten pat, p. 131], bet ir dvasinis pasaulis, praradęs gyvastị, merdi, apie ką rašè Vydūnas, S. Šalkauskis ir kt. Todèl „švietimo sistema - tai ne tik jaunosios kartos auklëjimo ir lavinimo būdas - tai galingas kuriantysis veiksnys, t. y. subjektas pačioje kultūroje, ypač kiekvienos sistemos aukštesnioji grandis - aukštosios mokyklos" [ten pat, p. 143].

Kaip vertybinis klodas jungtinas i švietimo sistemą? Jau 1988 m. koncepcija grindžiama triada žmogus-tauta-kultūra, pabrèžiant, kad žmogus yra savaiminè, nekintama vertybè. Toks vertybių atskaitos taškas leidžia dvasinèms vertybèms skirti prioritetinę vietą, o jų ugdymą laikyti svarbiausia kultūrinio gyvenimo dalimi, susaistyta būties ir buities peripetijomis. Iš čia išplaukia ir Lietuvos švietimo koncepcijos principai: humaniškumo, nacionalumo, demokratiškumo ir kaitos, kurie užtikrina dvasinių vertybių šiuolaikinę sklaidą, išlaikant fundamentinius pagrindus.

Verta pastebèti, kad ịvairiais aspektais artinantis prie dvasinių vertybiu, nurodomos ir jų transcendentinès prieigos, pabrėžiama pasaulèžiūrinių nuostatų svarba. Antai aptariant humanistinès psichologijos (A. Maslow) požiūrị i save aktualizuojančius žmones, ryškinamas ne jų užsisklendimas savyje, o veikimas socialinëje kultūrinëje erdvëje, ǐžvelgiant ir transcendencijos metmenį, kuris, kaip žinia, esminè dvasinių vertybių žymè. Juntamas jis ir UNESCO iškeltame siekinyje „mokytis būti kartu“, kurio (transcendentinio metmens) „kontekste prasmés atspalvị igauna iš dalies ir kiti siekiniai bei tikslai“" [ten pat, p. 377].

Vertybinis aspektas svarbus ir skiriant šiuolaikines ugdymo tendencijas ị du stambius srautus: pragmatinị-technologinị ir humanistinį-kultūrinị. Pastarąji M. Lukšienè supranta plačiausia žmoniškumo prasme kaip „nuolat besikeičiantí, tačiau išlaikantị ir pastovumo branduolị - žmoniškumo esmę " [ten pat, p. 373], kuri susijusi „ir vertybinemis nuostatomis, ir dorovinemis normomis, ir naujausiomis mokslo teorijomis apie bręstančio žmogaus pasaulèvaizdžio formavimąsi“" [ten pat, p. 379]. Kita vertus, skiriamoji tarp minètu srautu - ugdymo orientacijų požiūriai: ar vertybinès nuostatos plètojamos asmens ir socialiniuose-kultūriniuose procesuose atskirai, ar žvelgiama $\mathfrak{i}$, ,asmens ir visuomenès santykius jų abieju kaitoje, t. y. dabartyje ir ateities perspektyvoje" [ten 
pat, p. 374], îkūnijant aktyvią gyvenimo humanizaciją. Pastebètina, kad tik visuminis požiūris ị asmenị ir kultūrą gali laiduoti vertybinị ugdymą, suteikiantị reikšmę, ịprasminantį praeities, dabarties ir ateities sąlytị. Šiuo atžvilgiu Daktare išryškina svarbiausią ugdymo proceso sandą - ugdymo tikslus. Kadangi jie iš esmès siejasi su dvasine dimensija, ir tiek materialistine, tiek pragmatine filosofija remiant ugdymą, praranda šiais atžvilgiais apčiuopiamą konkretumą, kartu ir reikšmingumą, pabrěžiama, kad „ypač svarbu gerai suvokti ugdyme kiekvieno žingsnio ị ịprasmintą tikslą trumpalaikes ir ilgalaikes veiklos atkarpas bei jų numatomus tikslus“", kurie „visą laiką lieka orientuoti i tolimąji tikslą ir persunkti siekiamos prasmès" [ten pat, p. 374].

Iškeliamas ir kitas pavojus, kai solidarumo, taikos, laisvès, socialinio teisingumo idèjos tampa patogia deklaracija, kartais sukeliančia priešingą, negatyvią reakciją, visų normų, o kartu ir vertybių neigimą, mosuojant madinga laisvés dèl laisvés vèliava, „kai nenorima kalbèti nei apie atsakomybę, nei apie pareigas" [6, p. 77]. M. Lukšiené, suprasdama situacijos sudètingumą, retoriškai klausia, ,ar šiandien būtų tikslinga ugdymui laikytis neutralių poziciju vertybių atžvilgiu?" [7, p. 378], kai „kultūros politikoje reiškiasi tam tikra dezorientacija tariamu laisvès vardu“, kai „masinès visuomenès modelis ir jo socialinè struktūra ir diktuoja kultūrinès raiškos formas" [ten pat, p. 348], savotiškai užvaldo kultūrinę sąmonę, atskirais atvejais prilygstančią fundamentalizmui. Tad kartu su V. Kavoliu natūraliai kyla klausimas, „ligi kiek ir kaip galima išklibinti tradicinès normos šaknis, kad nepažeistum žmogiškosios esmės?" [ten pat, p. 379]. Šioje keblioje situacijoje, ieškant asmens ir visuomenès lūkesčių dermès kultūros erdvèje, išsaugant pastovumo ir tęstinumo elementus pačioje kaitoje, siūloma ieškoti joms bendro vardiklio. Juo laikoma „bendražmogiškosios vertybès, kitaip tariant, dvasinès vertybinès nuostatos, igaunančios naujas formas gyvenimui kintant, tačiau turbūt negalinčios neigti paties žmogaus žmoniškumo - jo esmès" [ten pat, p. 350]. Ji (žmoniškumo esmè) turètų tapti tiek tèvu, tiek pedagogu, tiek visos visuomenès pamatiniu rūpesčiu, o idèjos, vertybinès nuostatos, „orientuotosịkonstruktyvu žmonių samb ū vị “ taptų vienu iš „svarbiausiųjų žmogaus, žmonių grupių, kultūrų vertinimo matmenų " [ten pat, p. 365].

Prie šios problemos glunda ir atvirumo eskalavimas, tačiau nesuprantant, „koks atvirumo santykis su esančiu vaiko, visuomenès kultūros turiniu ir pagrindinemis tendencijomis" [ten pat, p. 360], atviros visuomenès, atviros mokyklos siekiai gali taip pat skatinti destruktyvius procesus, kylančius iš visumos nepajautimo, filosofiškai sakant, vienio ir daugio disharmonijos. Kylant tokiems pavojams, verta konkretinti atvirumo sąvoką, kuri saistoma su galimybėmis, A. Lobato žodžiais tariant, galia „tapti tuo, kuo dar nèra" [6, p. 196], o tai gali laiduoti žmogui iškiliausius pasiekimus, kai jis per pažinimą atsiveria naujiems būties tiesos, gèrio, grožio turiniams. Kitaip tariant, „žmogus privalo pažinti tiesą, atsiduoti jos transformuojančiai ịtakai ir perduoti ją ¿̇vairiausiais būdais: ženklais ir žodžiais, jei tai protu suvokiama tiesa, bei pačiu gyvenimu, jei tai tiesa, kuriai reikalingas paliudijimas" [ten pat, p. 201]. Tad atvirumas tuo prasmingesnis, kuo giliau suvokiamas būties, reiškiamos įvairiomis formomis, vienumas, kai, vaizdžiai sakant, medžių gausa neužgožia miško sampratos, ar, kaip išsitaria M. Lukšiené, kai jis (atvirumas - atdarumas) remiasi $i$,,informacijos ịvertinimą, atsirinkimą, perdirbimą pagal savo struktūras ir pagaliau internalizavimą - interiorizavimą " $[8$, p. 396], kad naujovés darniai susijungtu i sistemas, išlaikančias ryšst tarp sena ir nauja.

Šalia konceptualaus žvilgsnio ị vertybiu vietą ugdymo, o dar plačiau - kultūros kontekste, M. Lukšienè daugelyje vietu stabteli prie atskirų vertybiu, kurios labai svarbios dabarties situacijai. Bene dažniausiai grę̌iamasi $\mathfrak{i}$ dorovines vertybes, giliausiai išreiškiančias asmens ir tautos dvasinį veidą. Tarp jų iškyla orumas, be kurio negali būti inteligento, kuris giliausiai tapatinamas su tokiu asmens autonomiškumu, kuris „nežeistų kito žmogaus orumo“ [7, p. 161], kur „visi valstybès kūrybos veiksmai“ [ten pat, p. 382] būtu grindžiami tautos, valstybès ir jos piliečio, kitaip sakant, dalykiškai pagrịstu tautiniu orumu, laikomu būtina prielaida siekiant prestižo, nesuvedant jo ị prabangias reprezentacijas, o daugiau rūpinantis tautos mentaliteto kèlimu, kai taip dažnai, M. Martinaičio žodžiais tariant, „t yči o ja masi iš to, kas gali ir turi išlikti" [ten pat, p. 363], kai „susidariusi situacija palanki skatinti daugelio vertybinių orientaciju - altruizmo, solidarumo, žmogiško orumo ir kt. nuvertèjimą" [ten pat, p. 364]. Orumas, pasak minèto A. Lobato, kyla visu pirma iš jo priklausomybès dvasinei būties sričiai" [ 6 , p. 70], todèl „dvasiškumas turi nulemti visą žmogaus gyvenimą" [ten pat, p. 72]. Svarbus žmogiškojo orumo rodiklis yra savigarba, kurios trūkumą rodo „ž o džių ir darbų neatitikimas, dirbamo darbo humaniškos esmés nesupratimas ir jo dangstymas formalumais" [7, p. 303], taip būdingas ypač institucinèje veikloje.

Švietimo reformos kūrèjams teko savaip gryninti vertybių, ypač dorinių, turinio sampratą, kad 
tautiškumas nesikirstų su pilietiškumu, tolerancija netaptu pakantumu abejingumui bei priedanga antidorovinei veiklai, patriotizmas nebūtų tapatinamas tik su ritualais ir simboliais, saviraiška nevirstų sauvalès apraiška ir kt. Dedant naujos švietimo sistemos pagrindus, jos visi kampai turëjo remtis, bent neprasilenkti su dora, tiesiogiai reiškiama ar implikuota i kitas erdves, bet išlaikanti esminị tiesos matmenị, kurio pagrindu kildinami santykiai, atlaikantys dinamiškus praeities, dabarties, ateities kontekstus, nes „žmogus visų pirma turi išaugti žmogumi, o paskui eina visos kitos jo savybès ir privalumai" [ten pat, p. 318]. Kartu M. Lukšiené primena, kad „dorinis ugdymas $\langle\ldots . .>$ apima ne vien žmogaus santykị su pačiu savimi, Dievybe, bet ir su kitu asmeniu, visuomene" [ten pat, p. 320], tapdamas viso ugdymo epicentru ir giliau ar sekliau persmelkia visas veiklas, nukreiptas i „autentiškumo, žmogiškos prasmès paieškas kiekviename ugdymo žingsnyje" [ten pat, p. 371]. Tokia prasmé susaisto buvusias, esamas ir būsimas kartas įsisąmonintais ar tik numanomais žmoniškumo saitais, kurie naujose situacijose keičia raiškos formas, bet ne esmę. Ji nepasiduoda reliatyvizmo diktatūrai, o remiasi, A. Lobato žodžiais tariant, mintimi, kad „žmogus didingas, nes yra pasirengęs priimti tiesą, gali ịsisavinti fundamentalias tiesas ir remdamasis jomis kurti neišsemiamą kultūros įvairovę“ [6, p. 202].

\section{Šiuolaikiniai ugdymo problemų židiniai}

Seniai pastebèta, kad jei negalima kurio reiškinio suprasti, paaiškinti, reikia ne ji skaidyti ị smulkesnes dalis, bet, priešingai, tarsi atsitraukti reikiamu atstumu, kad būtu galima ji visą apimti. Holistinis požiūris ị pažinimą yra išmintingųjų kelias, susiejantis įvairias pažinimo prieigas, jų persipynimą. Ypač jos sudètingos mąstant apie žmogaus ugdymą, visu pirma jo pažinimą. Tai pasaulinė problema, kurią spręsti konkrečiose situacijose pašaukti pedagogai. Minètas ispanų filosofas A. Lobato teigia, kad „reikalingi pedagogai, sugebantys aprépti visumą, užgriebti gilumą, îsisavinti tiesą bei pakilti virš kasdienybès smulkmenu“" (2001, p.112), t. y. dvasiškai brandūs pedagogai.

Tokiomis idejjomis, kaip minèta, grindžiama Lietuvos švietimo reforma: nuo pirmų jos žingsnių keltas asmens ir kultūros vienumas, ženklintos metodologinès ugdymo gairès. Tai iškilūs siekiai, kuriems ịgyvendinti taip pat reikia iškiliu asmenybių, atitinkamos bazės, laiko. Esant labai plačiam darbų barui, lengviau buvo galima sutelkti pajègas ugdymo programų, turinio, strategijų, metodų, pažangos ir pasiekimų vertinimo kaitai, sunkiau - pedagogu profesiniam ir dvasiniam brandinimui, pašaukimo puoselëjimui. Padètị sunkino tai, kad asmens ir kultūros sklaida, jų simbiozè, kylanti iš dvasinès dimensijos ir apimanti visas gyvenimo sritis, pragmatizmu alsuojančiam pasauliui atrodo nereikšmingos, juolab kad tai ilgas ir sudettingas procesas, netenkinantis sparčios kaitos poreikių. Kartu pedagogu darbo vertinimas, būsimu pedagogu rengimas lieka ugdymo problemų židiniu, atvira problema, kurią nuolat eskaluoja šiuolaikinè žiniasklaida. Pastebèjo ją ir Daktarè, primindama, kad reformos pradžioje dèmesys buvo fokusuotas i mokini, vadovèlių rengimą, „kad pašviestume kelius mokytojui“ [7, p. 256], o pedagogu asmenine bei kultūrinè kaita liko daugiau fragmentinio pobūdžio: jų patirtys, nuostatos, brandintos totalitarinëje sistemoje, išmoktas pamokas kèlè ị naują paradigmą, blokuodamos tikrąją jos esmę, atverdamos duris pragmatiškumui, imitacijai. Tai rodo ir nuolat keičiami pedagogu rengimo reglamentai, ir pedagogų rengimo turinys, ir pedagogo misijos sutapatinimas su paslaugų teikimu, taip eliminuojant jos dvasinę esmę, kuria pulsuoja M. Lukšienès mintis, kartu nurodant, kad mokytojas ,sudaro sąlygas, padeda, veda vaiką ị brandų asmenị ir patirtịi" [2000, p. 265].

Dvasinès dimensijos stygių dar daugiau ryškina technokratijos dominavimas, kai „žmogaus dvasinę brandą lenkia technika su jos primetama kultūrine struktūra ir atmosfera" [ten pat, p. 58], kai žinios komercializuojamos, kai „prekybinį, biznio modeli bandoma perkelti ị dvasinę žmonių bendravimo sritị“ [ten pat, p. 374], o šis (modelis) įneša „pakaitas ne vien ị materialinę, bet ir ị dvasinę žmogaus erdvę" [ten pat, p. 375]. Tuomet kyla „pažinumo ar vertybinių nuostatu pastovumo" [ten pat, p. 371], ugdymo efektyvumo problemos, kurias svarbu „sąmoningai pasverti ir laiku koreguoti“ [ten pat, p. 375]. Tik tai darosi vis sunkiau, nes, kaip teigia V. Kavolis, ,šlamšto skleidimasis pradeda atrodyti natūralia tvarka, prieš kuri entropiją tegalima atlaikyti planingomis išorinés ir vidinés aplinkos saugojimo priemonèmis" [ten pat, p. 354]. Ugdymo plotmëje ypač tenka atkreipti demesį i du šiuolaikinių ugdymo problemų židinius - tikslu kèlimą ir metodu sureikšminimą. Pirmasis, kaip viso ugdymo epicentras, nors mokykla ir pavadinta ugdymo institucija, didele dalimi lieka lavinimo plotmèje, nes „sunkiau dirbti ịsipareigojus jungti mokomuosius ir auklëjamuosius tikslus bei uždavinius į bendrus ugdomuosius, derinti metodus bei turinị “ [ten pat, p. 379]. Be to, auklëjamieji tikslai tiesiogiai išplaukia iš dvasinès asmens dimensijos, turi kitus atskaitos taškus, kitą ugdymo ir vertinimo strategiją. Jų kèlimui ir iggvendinimui labai svarbi 
paties pedagogo dvasinẻ branda, visuminis kultūros suvokimas, gebejjimas jausti perspektyvą ir jos mažus ženklus kasdienëje veikloje, santykiuose, ir, kas svarbiausia, liudyti savo gyvenimu. Jei tai neatsitinka, auklejimas eliminuojamas. Sunkina situaciją ir tai, kad auklëjimo negalima perkelti iš kitos šalies, išsiversti, nes dar XIX a. antrojoje pusejje buvo suprasta, kad jis skleidžiasi savosios kultūros terpëje. Todèl dabarties praktikoje dažnai fragmentinis vertybinių nuostatu susiejimas su ugdymo turiniu negali duoti laukiamų rezultatų. Nesusiorientavimą ar nenorą auklèti lengva pridengti ir galima vertybių indoktrinacijos vèliava.

Ugdymo tikslai subordinuoja visą ugdymo procesą. Vèlgi i jų vietą netiesiogiai kèsinasi ugdymo metodai, nes jiems, daugiausia atliepiantiems technologiju kaitą, skiriamas ypatingas dèmesys. Bet „metodas be krypties filosofinio suvokimo - plikas, mechaniškas dalykas, suardantis dvasingumą. Ji ardo ne tik mechaniškai suvokto metodo garbinimas, bet ir empirizmas (patirties kèlimas be teorijos, be koncepcijos, t. y. be tikslo)" [ten pat, p. 132], dèl ko dar 1988 m. persergi M. Lukšienè. Tuo tarpu tik pastaraisiais metais pasaulineje arenoje pasigirsta pavieniai balsai, siūlantys keisti ugdymo kryptị nuo technologijų, prie metodologijos, telkiant dèmesị ị žmogiškos būties tapsmo ir pagalbos jam ypatumus.

Skausminga problema lieka ir patriotizmo, nacionalines kultūros puoselejjimas. Tai dvasiniai gyvenimo pamatai, kurie, sunykę po pusės amžiaus totalitarinès sistemos viešpatavimo, pateko, pasak A. Andrijausko, i globalios metacivilizacijos raidos fazę, pasižyminčią vaizdo kultūros ekspansija. „Rašto knyginè civilizacija formavo vientisą pasaulio suvokimą, o iš tekančių vaizdų susidedanti iš ekranų perimama informacija gimdo kitoki - fragmentišką pasaulio suvokimą“ [žr. 4], sudarantị sąlygas kultūrinei konkurencijai, kurioje vis sunkiau išlaikyti savo ir tautinị orumą. M. Lukšienès proteguota pagrindinè švietimo reformos idejja, igalinanti sujungti asmenị, tautą, kultūrą, taip užtikrinant visų dėmenų optimalią raidą ir sklaidą, buvo kartu skydas nuo atsirandančių naujų grèsmių, kad laisva valia netaptume apgailètinais mankurtais savo Tèvynëje. I ugdymo institucijas buvo dedami didžiuliai lūkesčiai. Nedrąsu klausti, ar jie pateisinti? Jau pirmajame švietimo reformos dešimtmetyje Daktare atkreipia akis ị švietimo organizacijų tikslus, kuriuose „nèra nė užuominos apie bendrąją visuomenès ar tautos kultūrą“, kaip ir i tai, kad nebandoma svarstyti ugdymo požiūriu kylančių problemų dèl „didejjančio atotrūkio tarp elitinès ir masinès kultūrų“ [7, p. 383], juolab kad pastaroji greitai sukūrè galingą, ịtaigią raišką, savo- tišką kultūrinès sąmonės užvaldymą, kurị būtų galima „sąlygiškai priskirti tam tikrais atvejais ir fundamentalizmui“ " [ten pat, p. 348]. Jis trikdo ryšį, savitai naikina fundamentines dorovès versmes, kuriomis minta šiuolaikinio ugdymo prioritetai - pilietiniai, patriotiniai jausmai.

Sunkiai šaknijasi ir laisvès želmenys, kurie dažnai buvo suprasti paviršutiniškai, iškreipiant net demokratijos esmę, kai esminiais jos požymiais linkstama laikyti juridinès raidès laikymąsi, „formaliąją teisès funkcionavimo pusę, demokratinès visuomenès priedanga kurti oligarchinę jos sandarą" [ten pat, p. 348], tvirtinančią demokratijos fundamentalizmą. Tikroji laisve, kaip pastebi A. Lobato, yra „savęs ir savo veiksmų valdymas" [6, p. 76], vedantis prie gério, dar tiksliau, susietas su atsakomybe, gelmine sąžinès raiška. Kai laisvè praranda šị matmenị, ji tampa teisių, ne pareigu apoteoze, nukreipta ị reikalavimus kitiems, bet ne sau. Tik laisvas pedagogas gali būti veiksminga sąlyga, svarbiu veiksniu mokinio, o kartu ir visuomenès laisvėjimui. Ar pedagoginè bendruomenè atlieka šią misiją, kuri ịvairiuose kontekstuose keliama švietimo reformos kūrëjų? Ar patyčios mokykloje ne klaidingai suprastos laisvès vaisiai? Tai vis klausimai, i kuriuos reikia nedelsiant atsakyti, kad taurios idejos, keltos švietimo reformos pradininku, brandintų derlių.

\section{Išvados}

Dvasinio ugdymo ištakos - žmogaus būties kaip dvasinès, psichinès ir fizinès dimensijos sankirtos ir vienovès samprata. Dvasinė dimensija, antgamtinè tikrovès dalis, atlieka žmogaus tapsme pamatinę, vienijančią funkciją, bet ji nepasiekiama pozityvistiniais tyrimo metodais. Dèl to dvasinis asmens matmuo nesuvokiamas materializmo ir pragmatizmo apologetams, neparankus ir reliatyvizmo teoretikams. Tuo labiau ugdymo mokslininkams ir praktikams svarbu suprasti dvasinius asmens parametrus (laisvę, tiesą, meilę), ịsikūnijančius remiantis humaniškumo, nacionalumo, demokratiškumo ir kt. principais.

Švietimo reforma nuo jos užuomazgų grindžiama asmens ir kultūros sąsajomis, nes būtent dvasinè dimensija igalina žmogu būti asmeniu, kurti kultūrą ir save. M. Lukšienè laiko labai svarbiu dalyku visuminị kultūros suvokimą, o ugdymą - kultūros proceso sandu, kylančiu iš tų pačių dvasinių šaknų. Todèl asmens ir kultūros jungtys yra švietimo reformos pamatiniai dalykai.

Aptariant švietimo bei kultūros, o kartu ir ugdymo kaitos ir pastovumo santykị, Daktaré atkreipia dèmesi i dvasines vertybes, laikydama jas dabarties ir 
ateities mokyklos bendru vardikliu, švietimo reformos garantu. Kartu pristato dvasingumo sampratą, implikuojančią vertybių internalizaciją, transcendentinio matmens gijas, gilinasi ị laivès, atvirumo, orumo esmę ir sklaidą mokykloje, reiškia susirūpinimą doriniu, tautiniu, pilietiniu ugdymu.

Šiuolaikiniai ugdymo problemų židiniai mokykloje kyla taip pat iš dvasinio ugdymo gelmès. Didžiausią rūpestị kelia pedagogų darbo vertinimas ir jų rengimas; žinių komercializacija ir su ja susijusių verslo modelių perkèlimas ị dvasinius santykius; ugdymo tikslų kèlimas, eliminuojant dvasines vertybes ar nesuvokiant jų ugdymo(si) mechanizmų; ugdymo metodų sureikšminimas; patriotizmo, nacionalinès kultūros puoselëjimas, laisvès ribos, ị ką kreipè dèmesị M. Lukšienė.

\section{Literatūra}

1. Frankl V. Dešimt tezių apie asmenybę. In: Sielogyda. Gydytojo rüpestis - siela. Dešimt teziu apie asmenybe. Vilnius: Vaga, 2007, p. 335-346.

2. Jokubaitis A. Tautine valstybe ir atsakomybè. In: Vertybiu nykimas? Rimtas požiüris $\dot{z}$ atsakomybe. Vilnius: Demokratines politikos institutas, 2008, p. 11-34.

3. Kriščiūnas K., Staniškis J. K., Tričys V. Moksline veikla: šimolaikines tendencijos. Šiauliai: ŠU leidykla, 2008.

4. Kutkaitytė M. Mąžtantis visuomenès raštingumas: pražūtinga nieko nedaryti [žiūrèta $2013 \mathrm{~m}$. balandžio 1 d.]. Prieiga per interneta: $<\mathrm{http}: / /$ www. delfi.lt/news/daily/lithuania/maztantis-visuomenes-rastingumas-prazutinga-niekonedaryti. $\mathrm{d}$ ? id= 61037787\#ixzz2PDHroXoP $>$.

5. Laiko prasmès: [Julijos Biliūnienès-Matjošaitienès atsiminimai: dukters pasvarstymai: medžiaga besiformuojančios lietuviu inteligentijos mentalitetui suvokti] / Julija Biliūnienè-Matjošaitienè, Meilè Lukšienè. Vilnius: Lietuvių literatūros ir tautosakos institutas, 2004.

6. Lobato A. Žmogaus orumas ir likimas. Vilnius: Logos, 2001.

7. Lukšienė M. Jungtys. Vilnius: Alma littera, 2000.

8. Martišauskienè E. Paauglin dvasingumas kaip pedagoginis reiškinys. Vilnius: VPU leidykla, 2004.

9. Wojtyła K. Asmuo ir veiksmas. Vilnius: Aidai, 1997.

10. Маслоу А. Аальние иредельг человеческой психики. Санкт-Петербург: Евразия, 1997.
Summary

Elvyda Martišauskienè

\section{IMPORTANCE OF SPIRITUAL EDUCATION FOR PRESENT AND FUTURE SCHOOL: M. LUKŠIENĖ'S INSIGHTS}

Spiritual education derives from the conception of a human being as intersection and unity of spiritual, psychical and physical dimension. Spiritual dimension, as a part of supernatural reality, performs a fundamental and unifying function in the becoming of an individual but it is not approachable through positivist research methods. Due to this reason, spiritual dimension of personality is inconceivable to apologists of materialism and pragmatism, unapproachable theoreticians of relativism. Therefore, it is particularly important to understand spiritual parameters of an individual (freedom, truth, love) that manifest themselves through principles of humanism, nationality and democracy.

Since its very beginning, the education reform has been grounded on links of an individual and culture because namely, the spiritual dimension enables a human being to become a personality, to create culture and oneself. M. Lukšienè perceives holistic understanding of culture as a highly relevant aspect and education as a component of culture process, which derives from spiritual roots. Therefore, links of personality and culture are fundamentals of education reform.

Discussing the relation between change and stability of education, M. Lukšienè directs our attention to spiritual values, approaching them as common denominator of present and future school as well as a guarantee of education reform. She also presents conception of spirituality, links of transcendental dimension, penetrates into the essence and spread of freedom, openness and dignity, and raises concern about moral, national and civic education.

Contemporary focuses of education problems emerge at school deriving from the very depths of spiritual education. The main concern regards evaluation of teachers' work and their training; knowledge commercialisation and transfer of related business models to spiritual relations; establishment of education goals eliminating spiritual values or failing to understand mechanism of their (self-)development; prioritisation of education methods; nurturance of patriotism, national culture, limits of freedom and other aspects, which were pointed out by M. Lukšiené.

Keywords: spiritual education, interaction of individual and culture, focuses of education problems.

Lietuvos edukologijos universitetas, Iteikta $2013 \mathrm{~m}$. gegužes mèn. 